\title{
THE CONTRASTING RESPONSES OF MUSCOVITE AND PARAGONITE TO INCREASING PRESSURE: PETROLOGICAL IMPLICATIONS
}

\author{
CHARLES V. GUIDOTTI ${ }^{\S}$ \\ Department of Geological Sciences, University of Maine, Orono, Maine 04469-5790, U.S.A. \\ FRANCESCO P. SASSI \\ Dipartimento di Mineralogia e Petrologia, Università di Padova, C.so Garibaldi 37, I-35137 Padova, Italy \\ PAOLA COMODI AND PIER FRANCESCO ZANAZZI \\ Dipartimento di Scienze della Terra, Piazza Università, I-06100 Perugia, Italy \\ JAMES G. BLENCOE \\ Chemical and Analytical Sciences Division, Oak Ridge National Laboratory, P.O. Box 2008, Oak Ridge, \\ Tennessee 37831-6110, U.S.A.

\begin{abstract}
The incorporation of $\mathrm{Fe}, \mathrm{Mg}$, and $\mathrm{Si}$ into muscovite in response to increase of pressure $(\mathrm{P})$ has long been recognized. In the context of the appropriate mineral assemblages, the extent of this substitution has been calibrated to serve as a very useful geobarometer for high-P parageneses. In marked contrast, little or no Fm i.e., $\Sigma\left(\mathrm{Mg}+\mathrm{Fe}_{\mathrm{total}}\right)$, substitutes into paragonite regardless of P. To date, Fm substitution into muscovite has been considered only in terms of $\Delta V_{\mathrm{r}}$ with little consideration of the crystallochemical aspects of this substitution. Moreover, the substitution seems to occur in response to simple exchange-reactions involving little or no dehydration. Such reactions typically have a negligible $\Delta V_{\mathrm{r}}$. Drawing upon the implications of studies combining high-P refinement of the crystal structures and measurement of compressibility, we suggest that high P causes structural changes in low-Fm muscovite that destabilize it. However, implementation of the Fm substitution facilitates structural adjustments, which reduce this instability. In contrast, paragonite is not only intrinsically less compressible than muscovite, but any substantial amount of Fm substitution would destabilize it.
\end{abstract}

Keywords: muscovite, paragonite, celadonite, mica, crystal structure, compressibility, high pressure.

\section{SOMMAIRE}

On connait depuis longtemps l'incorporation du $\mathrm{Fe}$, du $\mathrm{Mg}$, et du $\mathrm{Si}$ dans la structure de la muscovite en réponse à une augmentation de la pression (P). Dans le contexte d'assemblages de minéraux appropriés, la portée de cet écart par rapport à la composition idéale sert de géobaromètre très utile pour étudier les paragenèses formées à pression élevée. Il est remarquable, par contre, que très peu du composant Fm, c'est-à-dire $\Sigma\left(\mathrm{Mg}+\mathrm{Fe}_{\text {total }}\right)$, est incorporé dans la paragonite, quelle que soit la pression. Jusqu'à maintenant, on a rationalisé l'incorporation de Fm dans la muscovite uniquement en termes de $\Delta V_{\mathrm{r}}$, sans trop se préoccuper des considérations cristallochimiques de cette substitution. De plus, la substitution semble intervenir en réponse à de simples réactions d'échange impliquant très peu de déshydratation ou bien sans déshydratation. De telles réactions typiquement on une valeur très faible de $\Delta V_{\mathrm{r}}$, ou bien elle est nulle. Nous tirons profit des études récentes des structures à pression élevée et des mesures de leur compressibilité, et nous proposons qu'à pression élevée, des changements structuraux mènent à la déstabilisation de muscovite à faible teneur en Fm. L'incorporation du composant Fm facilite les ajustements structuraux, et réduit ainsi cette instabilité. En revanche, la paragonite serait non seulement intrinsèquement moins compressible que la muscovite, mais toute ajout du composant Fm mènerait à sa déstabilisation.

(Traduit par la Rédaction)

Mots-clés: muscovite, paragonite, céladonite, mica, structure cristalline, compressibilité, pression élevée.

§ E-mail address: guidotti@maine.maine.edu 


\section{INTRODUCTION}

Regardless of a rock's bulk composition or mineral assemblage, an increase in metamorphic pressure leads to an increase in the $\mathrm{Fe}, \mathrm{Mg}$, and $\mathrm{Si}$ contents of muscovite (Ms), i.e., in the solid solution toward celadonite (Ernst 1963); at the same time, $\mathrm{Na} /(\mathrm{Na}+\mathrm{K})$ and $d(002)$ decrease. In contrast, the composition of paragonite $(\mathrm{Pg})$ is largely unaffected by increasing $\mathrm{P}$. In this paper, we discuss crystallochemical and compressibility data for muscovite and paragonite that shed light on these observations. Some of the crystallochemical data and many of the petrological details are presented in Sassi (1972), Guidotti \& Sassi (1976, 1998) and Guidotti et al. (1989, 1992, 1994a, b). Moreover, Sassi et al. (1994) and Guidotti \& Sassi (1976, 1998) have reviewed how the occurrences of muscovite and paragonite (including their polytypes) and muscovite-paragonite immiscibility are strongly correlated with P-T conditions of crystallization. For mica compressibility, we will utilize (a) the results of Hazen \& Finger (1978), which show that layer silicates (phlogopite and chlorite) are highly compressible, especially along the $c$ dimension, and (b) the recently published data of Comodi \& Zanazzi (1995, 1997), who combined compressibility data and crystalstructure refinement results for three carefully chosen, naturally occurring muscovite and paragonite specimens, all with compositions that are essentially in the $\mathrm{Na}-\mathrm{K}$ pseudobinary system muscovite-paragonite and having $\mathrm{Na} /(\mathrm{Na}+\mathrm{K})$ values of 7.14, 38.14, and 88.0 mole $\%$. The parageneses of these micas are summarized in Comodi \& Zanazzi (1995, 1997). The sodian muscovite with a $\mathrm{Na} /(\mathrm{Na}+\mathrm{K})$ value of 38.14 mole \% essentially lies at the Na-limit for muscovite on the muscovite-paragonite solvus proposed by Guidotti et al. (1994a). The results of Comodi \& Zanazzi $(1995,1997)$ are summarized in Figure 1 and in the next paragraph.

\section{Crystallochemical Aspects}

Two key results of the compressibility and highpressure crystal-structure work simultaneously performed by Comodi \& Zanazzi $(1995,1997)$ can be summarized as follows: (1) the observed compressibilities and crystal structures at high pressure are systematically related to the $\mathrm{Na} /(\mathrm{Na}+\mathrm{K})$ values of the three micas studied, and (2) the changes in structure occurring as a function of pressure affect the stability of the micas, especially muscovite. Also affected are the crystallochemical behavior of muscovite and paragonite in various petrological and structural regimes. In particular, important effects on the intrinsic stability and crystallochemical behavior of muscovite occur because of the following changes observed in the isochemical high-P studies (see Appendix Table 1 for details).

(1) Increased $\alpha$ rotation (defined as rotation of the tetrahedra within the plane of the sheet of tetrahedra: Bailey 1984), plus large decreases in interlayer thick-
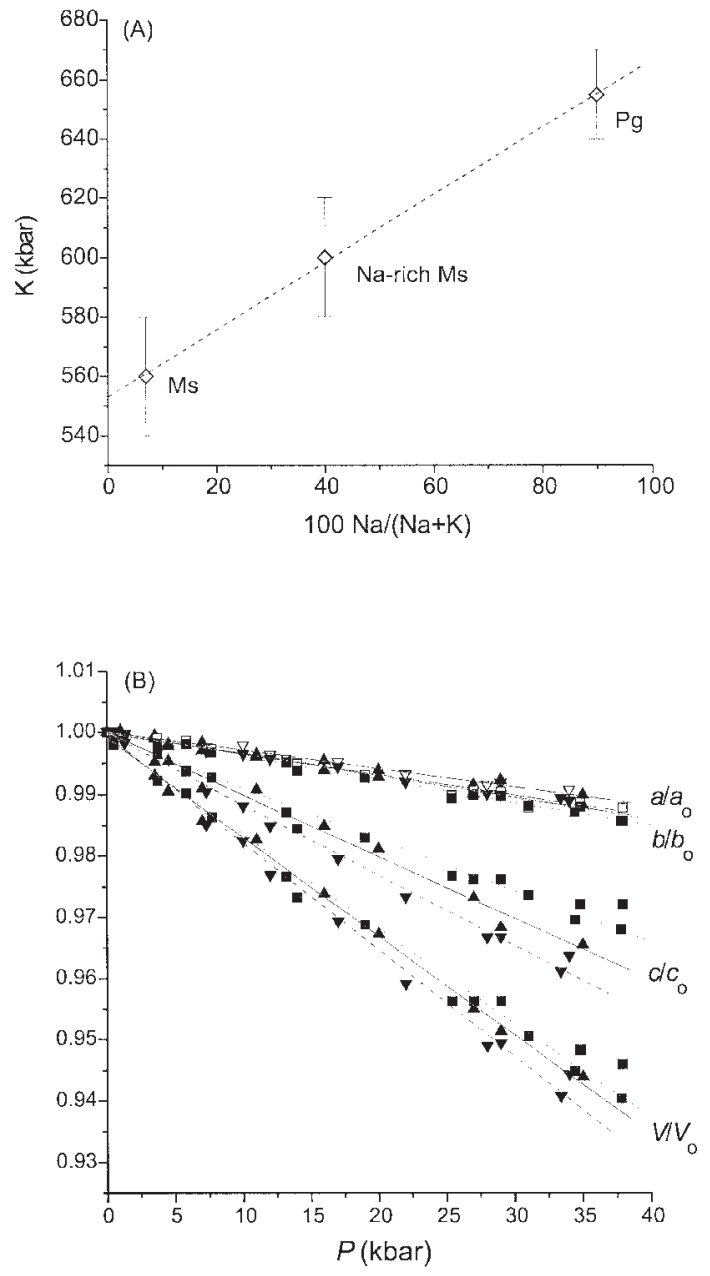

FIG 1. Compressibility data from Comodi \& Zanazzi (1995, 1997). (A) Variation of K, the bulk modulus, with the Na/ $(\mathrm{Na}+\mathrm{K})$ ratio of white mica in the $\mathrm{Ms}-\mathrm{Pg}$ pseudobinary. (B) Comparison of unit-cell parameters normalized to room conditions; Ms: $\boldsymbol{\nabla}$ and dashed lines, Na-rich Ms: $\boldsymbol{\Delta}$ and solid lines, Pg: $\square$ and dotted line. Solid symbols are chosen for $V / V_{0}, c / c_{0}$, and $b / b_{0}$, and open symbols for $a / a_{0}$. It can be seen that the compressibility of the $a$ and $b$ cell parameters is quite similar for Ms, Na-rich Ms, and Pg, but markedly different for $V / V_{\mathrm{o}}$ and $c / c_{\mathrm{o}}$, decreasing progressively from $\mathrm{Ms}$ to $\mathrm{Pg}$.

ness lead to: (a) significantly shortened $\mathrm{K}-\mathrm{O}$ bond lengths, (b) closer proximity of highly charged cations in tetrahedral sites, and (c) greater repulsion of the basal layers of oxygen across the interlayer site (especially in Na-rich muscovite).

(2) The sheets of octahedra (VI) shrink, and especially they thin to near and beyond the minimum allowable thickness, $2.04 \AA$ according to Bailey (1984). This thinning causes strong repulsion between oxygen atoms 
on the top and bottom of the sheet (see the note in Appendix Table 1 concerning the thickness of the sheet of octahedra for the Na-rich muscovite at $27 \mathrm{kbar}$ ). As discussed below, in rocks, compositional changes of muscovite occur which counteract these destabilizing effects.

\section{Discussion}

Because the new compressibility and crystalstructure data discussed herein were obtained at room temperature, it is important to consider the potential effects of elevated temperatures (T). It is difficult to assess rigorously the effects of $\mathrm{T}$ on the compressibility of muscovite and paragonite, but by combining their low-T compressibility data with the low-P thermal expansion data of Catti et al. (1989), Comodi \& Zanazzi (1995) concluded that, as expected, T and P generally have opposite effects on muscovite. Unfortunately, combining two separate datasets precluded rigorous quantification of the opposing effects. For muscovite recrystallizing in the strongly preferred orientation of slates (Guidotti et al., in prep.), $\mathrm{T}$ is quite low and thus can probably be completely ignored. For Fm-rich muscovite [Fm: $\left.\Sigma\left(\mathrm{Mg}+\mathrm{Fe}_{\text {total }}\right)\right]$ in high-P blueschisteclogite terranes, the effects of $\mathrm{P}$ are probably dominant and more than counter any effects of T. Exceptions to this assumption might include muscovite that crystallized in deep-seated rocks at $\mathrm{T}=600^{\circ} \mathrm{C}$ (e.g., muscovite that formed at both high $\mathrm{P}$ and $\mathrm{T}$, as in the case of some rocks of the Western Alps (see data tabulation used in Guidotti et al. 1994b).

The most common effects of $\mathrm{P}$ discussed in the literature (e.g., Guidotti \& Sassi 1976, 1998) involve the relatively low-Al limiting assemblage muscovite + $\mathrm{K}$-feldspar + plagioclase with a coexisting $\mathrm{Fe}-\mathrm{Mg}$ phase, e.g., biotite. Indeed, the effect of $\mathrm{P}$ on the incorporation of $\mathrm{Mg}+\mathrm{Fe}^{2+}$ into muscovite (or conversely, the incorporation of $\mathrm{Si}$ ) in such assemblages is the basis for the well-known "phengite geobarometer" (Massonne 1981, 1993, Massonne \& Schreyer 1986, 1987, Velde $1965,1967,1968)$. Less attention has been given to more Al-rich assemblages, including those with an Al-silicate present. Nonetheless, as demonstrated in the compilations used by Guidotti et al. (1994a, b), the effects of $\mathrm{P}$ on muscovite and paragonite listed in Appendix Table 2 also occur in such assemblages. That increasing $\mathrm{P}$ causes an increase of the Fm content in muscovite over a wide range of aluminous bulk compositions has also been confirmed by experiments performed at extremely high P (up to $100 \mathrm{kbar}$ ) by Domanik \& Holloway (1996) for a high-Al bulk composition, and by Schmidt (1996) for a low-Al bulk composition (see Guidotti \& Sassi 1998, p. 841). In summary, as discussed in detail by Guidotti \& Sassi (1976, 1998), the bulk Al-content in mineral assemblages can markedly affect the extent to which Fm substitutes into mus- covite; however, for a given Al bulk-rock content, Fm incorporation into muscovite is P-controlled.

Previous attempts (e.g., Guidotti et al. 1992) to understand atomistically the effect of high $\mathrm{P}$ on the composition of muscovite centered on P-induced changes in the interlayer (XII) site. Now, in the context of the structural changes listed in Appendix Table 1, we suggest that the isochemical destabilizing effects described above act in concert to produce the chemical and structural changes reflected in the observations considered herein (Appendix Table 2). From this broader starting point, our reasoning parallels that of the abovementioned previous explanations, i.e., in rocks, muscovite undergoes a twofold compositional adjustment to mitigate the destabilizing effects caused by increasing P: (a) substitution of Fm for ${ }^{\mathrm{VI}} \mathrm{Al}$ mitigates the overthinning of the VI sheet and also lessens the increase in $\alpha$ rotation, which would otherwise lead to excessively short $\mathrm{K}-\mathrm{O}$ bonds; (b) an increase in $\mathrm{K} /(\mathrm{K}+\mathrm{Na})$ helps prop apart the $2: 1$ sheets, thereby keeping the basal atoms of oxygen from getting too close. These changes lead to larger cations in VI and XII sites and smaller cations in IV sites (Si replacing Al). The latter substitution also helps to counter the significant increase of $\alpha$ that occurs when muscovite is highly compressed.

As determined at the Earth's surface, Fm-rich muscovite has a markedly smaller $\alpha$ angle $\left(6-8^{\circ}\right)$ than muscovite. This produces a larger XII site which, as discussed by Bailey (1984), allows the alkali ions to sink deeper into the pseudohexagonal rings of basal oxygen atoms. Hence, compared to muscovite, there is a marked shortening of the $c$ unit-cell dimension. In contrast, the $a$ and $b$ cell dimensions are larger owing to the effects of Fm increase in the VI sites. As discussed by Guidotti et al. (1992), the net result is that at the Earth's surface, Fm-rich muscovite has a somewhat larger unit-cell volume than muscovite.

The combined compositional and structural changes described above for muscovite subjected to high P lead to a much less distorted crystal structure, especially compared to that produced in the isochemical compressibility experiments described above. In this context, Comodi \& Zanazzi (1995, p. 176) discussed studies suggesting that "the stability of micas largely depends on the degree of distortion of various layers". Assuming that the results of Hazen \& Finger (1978) on a trioctahedral mica can be extrapolated to dioctahedral micas, they concluded that "in high-pressure environments, micas with small $\alpha$ rotations and octahedral layers having high bulk moduli (i.e., less compressible) are more stable", as would be produced by the substitutions noted above.

Finally, it is notable that increases in Fm, K, and $\mathrm{Si}$ in muscovite due to increasing $\mathrm{P}$ cause its cell volume (as determined at conditions of the Earth's surface) to increase, which is seemingly at odds with an increase in P. However, this a well-documented observation 
(Guidotti et al. 1992). Presumably, muscovite is involved either in dehydration or exchange reactions with chlorite, such that $\Delta V_{\mathrm{r}}$ is either slightly negative or, as typical for exchange reactions, near zero.

\section{Conclusions}

Analysis of combined compressibility measurements and high-P crystal-structure refinements shows that high $\mathrm{P}$ destabilizes low-Fm muscovite. This destabilization is mainly related to bond lengths, bond angles, and dimensions of both the individual coordination polyhedra and the sheets of polyhedra. Consequently, muscovite changes chemically to counteract these P-induced instabilities. However, even though undergoing P-induced structural changes (Comodi \& Zanazzi 1997), coexisting paragonite shows no clearly discernible compositional adjustments at pressures up to $\sim 25 \mathrm{kbar}$. Possibly this constancy is related to the octahedrally coordinated $\mathrm{Na}$ in the interlayer sites and the associated intrinsically large amounts of $\alpha$ rotation (e.g., $16.0^{\circ}$ at $0.001 \mathrm{kbar}$ and $17.9^{\circ}$ at $25 \mathrm{kbar}$ ). Such high values of would hinder enlargement of the VI sheet, as would occur by significant incorporation of Fm. Guidotti et al. (1994a, b) presented similar arguments, suggesting that incorporation of more than minor Fm into paragonite would destabilize it. Finally, as seen on Figure 1, paragonite is inherently less compressible than muscovite. Hence, possibly the structural changes occurring as $\mathrm{P}$ increases impart less instability to a paragonite crystal than a coexisting muscovite crystal, thereby not requiring the compositional adjustment seen in muscovite.

\section{ACKNOWLEDGEMENTS}

Discussions with R. Hazen at various points in this work have been very helpful and are much appreciated. Research support of various types has been provided to the authors as follows: CVG: travel support from the University of Maine and from the Italian CNR via the "Short Term Mobility Program"; FPS: from Italian CNR and MURST; PFZ: from the Italian CNR and MURST (project on "Relations between structure and properties in minerals: analysis and applications); JGB: from the Geothermal Technology Program of the Office of Energy Efficiency and Renewable Energy, U.S. Department of Energy, under contract number DE-AC0596OR22464 with Oak Ridge National Laboratory, managed by Lockheed Martin Energy Research Corporation. Finally, the comments of R. Hazen and R.T. Downs as reviewers have been helpful and are much appreciated.

\section{REFERENCES}

Bailey, S.W. (1984): Crystal chemistry of the true micas. In Micas (S.W. Bailey, ed.). Rev. Mineral. 13, 13-60.

CAtTi, M. \& FerRaris, G. \& Ivaldi, G. (1989): Thermal strain analysis in the crystal structure of muscovite at $700^{\circ} \mathrm{C}$. Eur. J. Mineral. 1, 625-632.

Comodi, P. \& ZANAZZI, P.F. (1995): High-pressure structural study of muscovite. Phys. Chem. Minerals 22, 170-177.

$\&$ (1997): Pressure dependence of structural parameters of paragonite. Phys. Chem. Minerals 24, 274-280.

DOMAniK, K.J. \& Holloway, J.B. (1996): The stability and composition of phengitic muscovite and associated phases from 5.5 - $11 \mathrm{GPa}$ : implications for deeply subducted sediments. Geochim. Cosmochim. Acta 60, 4133-4150.

ERNST, W.G. (1963): Significance of phengitic micas from low grade schists. Am. Mineral. 48, 1357- 1373.

Guidotti, C.V., Mazzoli, C., Sassi, F.P. \& Blencoe, J.G. (1992): Compositional controls on the cell dimensions of $2 M_{1}$ muscovite and paragonite. Eur. J. Mineral. 4, 283-297.

\& SASSI, F.P. (1976): Muscovite as petrogenetic indicator mineral in pelitic schists. Neues Jahrb. Mineral., Abh. 127, 97-142.

$\&$

(1998): Petrogenetic significance of $\mathrm{Na}-\mathrm{K}$ white mica mineralogy: recent advances for metamorphic rocks. Eur. J. Mineral. 10, 815-854.

\& Blencoe, J.G. (1989): Compositional controls on the $a$ and $b$ cell dimensions of $2 M_{1}$ muscovite. Eur. J. Mineral. 1, 71-84.

\& Selverstone, J. (1994a): The paragonite-muscovite solvus. I. P-T-X limits derived from the $\mathrm{Na}-\mathrm{K}$ compositions of natural, quasibinary paragonite-muscovite pairs. Geochim. Cosmochim. Acta 58, 2269-2275.

SAssi, R. \& Blencoe, J.G. (1994b): The effects of ferromagnesian components on the paragonitemuscovite solvus: a semiquantitative analysis based on chemical data for natural paragonite muscovite pairs. $J$. Metamorph. Geol. 12, 779-788.

HAZEN, R.M. \& FingER, L.W. (1978): The crystal structures and compressibilities of layer minerals at high pressure. II. Phlogopite and chlorite. Am. Mineral. 63, 293-296.

Massonne, H.-J. (1981): Phengite: eine experimentelle Untersuchung ihres Druck-Temperatur-Verhaltens in System $\mathrm{K}_{2} \mathrm{O}-\mathrm{MgO}-\mathrm{Al}_{2} \mathrm{O}_{3}-\mathrm{SiO}_{2}-\mathrm{H}_{2} \mathrm{O}$. Ph.D. thesis, Ruhr Univ. Bochum., Bochum, Germany. 
(1993): Phengite geothermobarometry: applications and geodynamic implications. Plinius 10 (abstr.).

\& SCHREYER, W. (1986): High-pressure syntheses and $\mathrm{X}$-ray properties of white micas in the system $\mathrm{K}_{2} \mathrm{O}-$ $\mathrm{MgO}-\mathrm{Al}_{2} \mathrm{O}_{3}-\mathrm{SiO}_{2}-\mathrm{H}_{2} \mathrm{O}$. Neues Jahrb. Mineral., Abh. 153, 177-215.

\& (1987): Phengite geobarometry based on the limiting assemblage with K-feldspar, phlogopite, and quartz. Contrib. Mineral. Petrol. 96, 212-224.

SASSI, F.P. (1972): The petrological and geologic signifiance of the $b_{0}$ values of potassic white micas in low-grade metamorphic rocks. An application to the Eastern Alps. Tschermaks Mineral. Petrogr. Mitt. 18, 105-113.

Guidotti, C.V., Rieder, M. \& De Pieri, R. (1994):

On the occurrence of metamorphic $2 M_{1}$ phengites: some thoughts on polytypism and crystallization conditions of $3 T$ phengites. Eur. J. Mineral. 6, 151-160.

SchMidT, M.W. (1996): Experimental constraints on recycling of potassium from subducted oceanic crust. Science 272, $1927-1930$

VELDE, B. (1965): Phengitic micas: synthesis, stability, and natural occurrence. Am. J. Sci. 263, 886- 913.

(1967): The $\mathrm{Si}^{+4}$ content of natural phengites. Contrib. Mineral. Petrol. 14, 250-258.

(1968): The $\mathrm{Si}^{+4}$ content of natural phengites: a reply. Contrib. Mineral. Petrol. 17, 82-84.

Received February 9, 2000, revised manuscript accepted May 11, 2000.

\section{APPENDIX TABLE 1. SOME IMPORTANT CHARACTERISTICS OF MS COMPRESSIBILITY*}

\section{Effects of $\mathrm{Na} /(\mathrm{Na}+\mathrm{K})$ on compressibility}

- Compressibility is highly anisotropic in both Ms and Pg. Ratios of compressibility along the unit-cell edges for $\mathrm{K}$ - and Na-rich samples are: $\beta_{a}: \beta_{b}: \beta_{c}=1: 1.15: 3.55$ in Ms, and $1: 1.19: 3.46$ in Pg. Ms and Pg are both much more compressible along $c$, and have the same compressibility along $a$ and $b$.

- Isothermal bulk moduli are 490 kbar for Na-poor Ms and 540 kbar for Na-rich Ms, a $10 \%$ increase

- Na-rich Ms is about $15 \%$ less compressible than K-rich Ms along $c$. This difference is due entirely to higher compressibility along $c$ for the K-rich Ms. High-pressure refinement of the structure shows that the difference in compressibility between the Na-rich and K-rich Ms is largely due to the $30 \%$ difference in the $\mathrm{Na} /(\mathrm{Na}+\mathrm{K})$ ratio.

- For both micas, the strain ellipsoid is almost a rotation ellipsoid with the axis of maximum compression perpendicular to the mica layers.

- The layers of tetrahedra and octahedra have different compressibilities, the latter being more compressible. This results in an increase (over $28 \mathrm{kbar})$ of the $\alpha$ rotation by about $2^{\circ}(\sim 12 \%)$ for both micas, and in changes of the interlayer cation-oxygen bond lengths.

\section{Effects of pressure on crystal structure}

- At high $\mathrm{P}$, the main changes occur in the interlayer region: its contribution to the decrease of $c$ is six times greater than that of the intralayer portion of the mica structure.

- Of the coordination polyhedra, the alkali-bearing interlayer site changes the most by far. Moreover, $\mathrm{K}-\mathrm{O}$ inmer, the shorter bond, shortens more than the $\mathrm{K}-\mathrm{O}$ outer

- Intralayer polyhedra: (i) the shape and size of tetrahedra are independent of $\mathbf{P}$; (ii) the octahedra change moderately, their volumes decreasing and the sheet thinning.

- The changes in the sheets of tetrahedra and octahedra increase the misfit between them, thereby necessitating the increase of $\alpha$ rotation by the tetrahedra, by about $2^{\circ}$ : [Na-poor Ms: $10.3^{\circ} \rightarrow 11.9^{\circ}\left(\Delta=1.6^{\circ}\right)$; Na-rich Ms: $10.9^{\circ} \rightarrow 13.7^{\circ}\left(\Delta=2.8^{\circ}\right]$

- In response to high $\mathbf{P}$, the sheets of octahedra shrink and thin, approaching the lower limit of sheet thickness at $2.04 \AA$, where the oxygen atoms come into contact and strongly repel each other. 
Contrast of some structural features of $\mathrm{K}$ - and Na-rich Ms at different pressures

\begin{tabular}{|c|c|c|c|c|}
\hline & $\begin{array}{c}\text { K-rich Ms } \\
0.5 \mathrm{kbar}\end{array}$ & $\begin{array}{c}\text { K-rich Ms } \\
28 \text { kbar }\end{array}$ & $\begin{array}{l}\text { Na-rich Ms } \\
0.001 \mathrm{kbar}\end{array}$ & $\begin{array}{c}\text { Na-rich Ms } \\
27 \text { kbar }\end{array}$ \\
\hline Tetrahedron $\alpha$ rotation (in ${ }^{\circ}$ ) & 10.3 & 11.9 & 10.9 & 13.4 \\
\hline Tetrahedron sheet thickness (in $\AA$ ) & 2.262 & 2.237 & 2.219 & 2.259 \\
\hline Octahedron sheet thickness (in $\AA$ ) & 2.083 & 2.047 & 2.093 & 2.008 \\
\hline Interlayer thickness (in $\AA$ ) & 3.376 & 3.128 & 3.324 & 3.05 \\
\hline Volume interlayer (in $\AA^{3}$ ) & 309.3 & 300 & 302.4 & 297.5 \\
\hline Volume intralayer (in $\AA^{3}$ ) & 158 & 143.9 & 153.9 & 139 \\
\hline Corrugation of basal oxygen sheet ( $\Delta z$ ) (in $\AA$ ) & 0.239 & 0.215 & 0.226 & 0.207 \\
\hline
\end{tabular}

* for details, see Comodi \& Zanazzi $(1995,1997)$.

\section{APPENDIX TABLE 2. SOME EFFECTS OF PRESSURE ON STRUCTURE AND COMPOSITION OF Ms AND Pg*}

- Although $c$ decreases as Fm increases, cell volume increases because the increase of $a$ and $b$ overrides the decrease in $c$.

- In Ms, as Fm increases owing to rising $\mathrm{P}$, the $\mathrm{Na} /(\mathrm{Na}+\mathrm{K})$ ratio, the $\alpha$ angle and the basal spacing all decrease

- In Pg, Frm never occurs in significant amounts.

- The Pg-Ms solvus opens markedly with increasing $\mathrm{P}$, mainly awing to extensive migration toward $\mathrm{KAl}_{2}\left(\mathrm{AlSi}_{3} \mathrm{O}_{10}\right)(\mathrm{OH})_{2}$ by the $\mathrm{Ms}$-rich limb, primarily in response to point 2 above; in contrast, the Pg-rich limb moves very little.

- Guidotti et al. (1992), showed that $\Delta V_{\operatorname{mix}}$ is positive on the $\mathrm{Ms}$ side of the $\mathrm{Ms}-\mathrm{Pg}$ solvus, but negative or nil on the Pg side. Thus, the behavior described above under point 4 may be partly due to differences between the $V_{\text {ox }}$ for Na-K mixing on the Ms and Pg sides of the solvus.

- The $3 T$ polytype of Ms is much more common in the Fm-rich Ms of high $\mathrm{P}$, whereas $2 M_{1}$ predominates in the low-Fm Ms that crystallizes at lower P (see Sassi et al. 1994).

- Ms in newly developed slaty cleavage tends to be more Fm-rich than the unrecrystallized Ms in the intervening lithons.

* see also Guidotti \& Sassi (1998). Fm: $\Sigma\left(M g+F e_{\text {total }}\right)$. 